PIOTR CELEWICZ*

\title{
Blockchain - system operacyjny nowoczesnego miasta
}

\section{Blockchain - the Operating System of the Modern City}

\section{Streszczenie}

Niniejszy artykut dotyczy tematyki funkcjonowania nowoczesnych metropolii jak np. Smart Dubaj, w następstwie postęoraz oprogramowanie. Autor przedstawit innowacyine pomysty dla zastosowania cyfrowej kryptografii - blockchain które usprawniaja interakcje zachodzạce wewnatrz struktur nowoczesnych miast lub ich fragmentów, pomiedzy jej użytkownikam w operacjach finansowych, w partycypacij społecznej, administracii publicznej i szeroko pojetych usługach, wykorzystuja cych nowe cyfrowe media. Większość zaprezentowanych przykładów dotyczy rozwijanych pomystów, które są w fazie testów i wkrótce moga zostać wykorzystane jako najbardziej optymalne.

\section{Abstract}

The article pertains to the subject of the functioning of modern metropolises, such as Smart Dubai, as a consequence of civilisatonal progress that is currently happening on the basis of the latest technical solutions aided by electronics and software. The author presented innovative ideas of using digital cryptography-blockchain - which increases the efficiency of interactions that take place within the structures of modern cities or their fragments, between their users, in financial operations, public participation and administration and broadly understood services that use new digital media. Most of the presented examples refer to developing ideas that are in their testing phases and that we will soon be able to use as the most optimal ones.

Stowa Kluczowe: blockchain, miasta inteligentne, spoteczność informacyina,
Keywords: blockchain, smart cities, information society, future technology

if density and diversity give life, the life they breed is disorderly."

"Jeśli gęstość i różnorodność dają życie, życie, któremu hołduja, jest nieuporządkowane." [1]

[Jane Jacobs]

Struktura miasta w dobie galopującej cyfryzacji i informatyzacji społeczeństwa ulega nieustannym zmianom za sprawą dynamiki postępu technologicznego, rozwoju cywilizacji oraz wielkiego potencjału ekonomicznego, jakie niosą ze sobą innowacyjne i nowoczesne rozwiązania. Jako istotne kamienie
milowe definiujące obecny stan rozwoju, $w$ którym branża IT połączona jest z prawie wszystkimi dziedzinami życia, można tu wyszczególnic następujące etapy. Pierwszym i kluczowym procesem było upowszechnienie personalnego komputera takze Internetu w gospodarstwach domowych, instytucjach publicznych. Do kolejnego kluczowego etapu rozwoju technologii nalezy zaliczyc miniaturyzację podzespołów i urządzeń, tora umožliwita ich mobilnośc, popularnośc oraz powszechność. Obecnie prognozuje się, że właśnie takie rozwiązania charakteryzują się największym potencjałem ekonomicznym. Upowszechnienie się mikrokomputerów i spersonalizowanie, „if density and diversity give life, the life they breed [Jane Jacobs

In a period of galloping digitalisation and computerisation of society, the structure of the city undergoes
constant changes due to the dynamic of technological progress, the development of civilisation and the great economic potential brought by innovative an high-tech solutions. Among the essential milestones the IT industry is cont state of development in whic of life we can list the following stages. The first and key process has been the popularisation of the personal computer and the Internet in common households and public institutions. The next key stage of sation of components and devices that has made it possible for them to become mobile, popular and commonly available. It is currently being prognosticated that these types of solutions are characterised by the greatest economic potential. The widespread smartphones, the access of devices to the nue to data transmissions or the Internet has become possible thanks to dynamically developing technical in-
frastructure. The user of mobile devices (such as, for za sprawą smartfonów, dostępu urządzeń do sieci, transmisji nie rozwijającej sie infrastruktury technicznej. Użytkownik urządzeń mobilnych (jak np. telefon, tablet, laptop) otrzyma potencjał natychmiastowego dostępu do informacji, ale także do treści mediów cyfrowych, na każde żądanie oraz w prawie każdym miejscu aglomeracji, a nawet na terenach niezurbanizowanych. Proces przenikania sie dwóch światów (cyfrowego i realnego) wystepuiacy w prawie wszystkich dziedzinach wo i wania które niczym protezy sa odpowiedzia na nowe potrzeby funkcionowani spoteczístu informacyinego. Obszary rozwoju, wtórych rozwija sie cywizaca moga oznaczá korozwoju, ẃ kón rozwoju, wh korych rozwija się cywilzacja moga ozn aczac konicile nia nowoczesnego hiperpolaczonego spoleczenstwa [2], dla którego technologia może pelnic rolę systemu operacyjnego, odpornego na ataki hackerow oraz respektowanego przez wszystkie jednostki i podmioty, a jednocześnie prawdopoobnie wręcz niezbędnego do zycia.

Nieustannie rozwijająca się branża technologii cyfrowych stworzyła produkt nowoczesnej kryptografii jakim jest niezależna waluta cyfrowa. Wiele osób wcześniej sceptycznie odnosiło się do sensu inwestowania w wirtualny pieniądz, ale wyniki finansowe przedstawiają tę sprawę bardziej optym stycznie. Popularnosc tematu w mediach wysoko wywindowała, na przełomie kilku lat, wartość tego środka płatniczego, co niewatpliwie ma istotny wpływ na przyszłą ekonomię, która aktywnie, lecz nie bezpośrednio kształtuje rozwój miast architekturę oraz poziom życia.

Pierwsza zdecentralizowana Kryptowaluta - Bitcoin, stworzona w 2008r. przez osobę o pseudonimie Satoshi Nakamoto otworzyła nowy dział ery cyfrowej [3]. Od tego czasu powstają setki takich walut wystawionych i sprzedanych przez miliony użytkowników na giełdzie internetowej. Kryptowalute cechuje rozproszony system ksiegowy bazujacy na szyfrowa

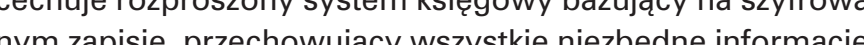
stanie posiadania, portfelach etc. Należy tu wspomiec, iz ten wituany pianiadz nie powstaby zapewne, gdyby nie

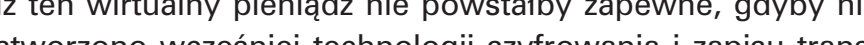

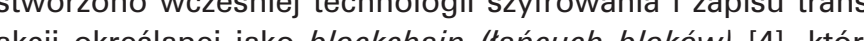

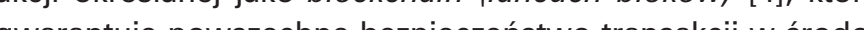
wisk kompunow i ntene wisku komputerow i ntemetu, a w konsekwencji wiarygodnosci i przeplyw srodkow plathiczych etc. Technologla blockchain, czyli lańcuch bloków, uchodzi za taką której nie da sie złamac, a służy do przechowywania i przesyłania informacj np.: o transakcjach zawartych $w$ Internecie, które ułożon są w postaci następujących po sobie bloków danych, któr zawierają informacje o określonej ilości liczb. W momencie zapelnienia blokow tworzą się kolejne po sobie wytwarzając swojego rodzaju tancuch. Średnio co 10 minut pojawia sie nowy blok, w ktorym moga byc przesylane informacje o róznych transakcjach, np. handlowych, stanów własności, udzialów, akcji, sprzedazy, kupna, a nawet wytworzeniu energi elektrycznej, albo dotyczących innych kryptowalut. Istotą b/ockchain jest utrzymanie wspólnej i zbiorowej „księgi rachunkowej transakcji", w postaci cyfrowej, rozproszonej po całej instance, a phone, a tablet or laptop) has been given the potential of immediate access to information, including digital media content, on demand and in in areas without urbanisation. The process of the merging of two worlds (the digital and the real one that is happening in practically every field of contemporary life has given people useful solutions that, like prosthetics, are the answer to the new needs of the velopment in which civilisation develops can signilyhe necessity of at least complementing, if not revising or redefining scientific theories concerning the structure and functioning of the modern, hypercon-

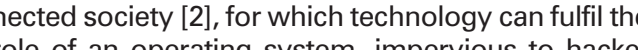
attacks and respected by all individuals and entities, while simultaneously being, in all probability, neces sary in our lives.

The ceaselessly developing digital technologies sector has created a product of modern cryptography people were sceptical as to the sense of investing in virtual money, but financial results have show this matter in a more optimistic light. The popularity of the subject in the media has, over the course of ayment mich, without a doubt, has an mportant impact on our future economy, which actively, although indirectly, shapes the development of cities, architecture and standards of living. The first decentralised cryptocurrency-Bitcoin, Satoshi 2008 by a person using the pseudony the digital age [3]. Since that time hundreds of such currencies have appeared, been set up and sold by millions of users on online marketplaces. Cryplocurrencies are characied on a distribcords that store all the necessary information: the state of one's account, porttolios, etc. It should be noted that this virtual money would probably not have been created had the encryption and transaction recording technology known as blockchain of the transactions within the environment of com puters and the Internet and, as a result, the reliabiity and flow of means of payment, etc. Blockchain echnology, which is a chain of blocks, is seen as unbreakable and is used to store and transfer inperformed over the Internet which are lacid out in the form of chains of sequential blocks of data that contain information about a specific amoun of numbers. When a block becomes filled, new sequential blocks are created, creating a sort of utes on average, enabling the transfer of inform ion about various transactions, e.g. commercial ones, ownership states, shares, stocks, selling, purchasing and even the production of electric rencies. The essence of blockchain is the maintenance of a shared and joint "transaction book" in a digital form, distributed all over the network. This data, provided it exists in the form of identical copies in many places simultaneously, is resistan altering data on all computers at the sampere of The technology is based on peer-to-peer networking, without the use of central servers or systems 
sieci. Dane te jeśli istnieją $w$ takich samych kopiach jednockerów, którzy nie są w stanie zmienić danych we wszystkich komputerach w tym samym czasie. Technologia ta opiera sie na sieci peer-to-peer (klient- klient) bez centralnych komputerów, systemów zarządzających i weryfikujących transakcje. Każdy komputer w sieci może brać udział w przesyłaniu i uwierzytelnianiu transakcji. Ksiega transakcji jest otwarta dla wszystkich, ale w petni zabezpieczona przed niepowotanym dostepem przez skomplikowane narzedzia szyfrujoce. Uży kownik, posiadajey klucz dostepu, ma jako jedyny wglad kow tylko $\mathrm{w}$ są publczno, ale i ukyte tak jak cala historia, od samego poczzyfu is do zamani ma niegraiczone zastosowa. Idea

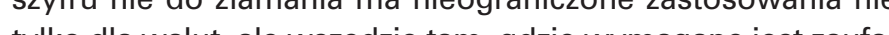
tylko dla walut, ale wszędzie tam, gdzie wymagane jest zau nie, ograiczony dostęp oraz dywersyfikacja danych.

Jako pierwsza to własnie branża finansowa rozpoznała potencjał blockchain, ale rownież ryzyko, ktôre ta technologia niesie. Od 2014 roku można zaobserwować ogromny wy-
syp start-upów, rozwijających technologie krypto walut. Jesteśmy świadkami powstania nowej branży, nazwanej od finansów i technologii finTech [5] wykorzystującej potencjal i powszechność technologii mobilnych oraz obrotu pieniędzy. W kolejnych latach $15 / 16$ powolane zostaio konsorcjum największych bankow (w skład weszły: m.in. Citi, Bank of America, Morgan Stanley, Societe Generale, Deutche Bank, HSBC, Barclays, Credit Suisse, Goldman Sachs, JP Morgan i ING) w celu rozwijania i aplikowania omawianych technologii. Następną branżą, która dostrzegła potencjał blockchain to energetyka, w której kryptografia świetnie nadaje sie do rozliczania transakcji kupna-sprzedaży energii pomiędzy jej małymi producentami, jak np. gospodarstwami domowymi, a ich klientami, niekoniecznie reprezentowanymi przez wielkich operatorów, a np. właścicielami samochodów elektrycznych. Zastanówmy sie jaki jest ideał miasta, wktórym chcieli byśmy żyć? Przede wszystkim jak pisze Richard Sennett . powinno być czyste i wezpieczne a w dalszejkolejnó́ci, posiadać wydajbyc cyste ibezpiecze, aw dalsze kold osci, pos. ne un

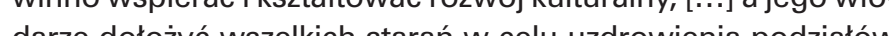

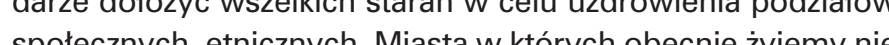

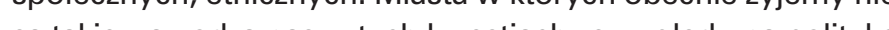
są takie, zaw edzą nas w tych kwesto ze wzgledu na polityke rządu, [...] nienaprawilne choroby spoleczne oraz przez utratę kapitalu ekonomicznego będącego poza kontrolą lokalną. [6] A zatem co dziś przybliza nas do idei nowoczesnego miasta? Niegdyś świeża, lecz jakże utopijna wizja Le Corbusiera dotycząca centrum miasta Paryża plan voisin,[7] skutkowałaby realnie zabiciem życia społecznego ulicy oraz obszarowo obiektowej izolacji funkcji, nie wspominając o zniszczeniu jakże bogatej i cennej tkanki historycznej. Był to najbardziej radykalny pomyst polegający na zastąpieniu zabytkowego centrum Paryża jako 3 milionowej metropolii nowymi sześćdziesięcio-piętrowymi wiezowcami mieszkalnymi, rozplanowanymi na regularnej siatce komunikacji i otoczonych zielenią oraz przestrzeniami rekreacyjnymi. Z perspektywy lat można zaobserwować, iż nie wszystkie myśli wizjonerskie zyskują pozytywne that manage and verify transactions. Every computer on the network can take part in the transfer and verification of transactions. The transaction book is open to all, but fully secured from unauthorise user that has an access key is the sole person able to look through their transactions. This ensures tha transactions are both public and hidden, as is their entire history, from the very moment of blockchain's of an unbreakable cipher has unlimited application not only for currencies, but everywhere where trus, limited access and data diversification is required. It was the financial sector that first identified the potential of blockchain technology, in addition to the
risks that this technology is associated with. Since 2014 we have been able to observe an immense rise in the number of start-ups that aim to develop cryptocurrency technologies. We are witnessing the birth of a new sector, named FinTech after a com-
bination of the words finance and technology [5] bination of the words finance and technology [5] to mobile technology and the flow of money. In the two years that followed, a consortium of the larges banks was formed (including, among others, Citi, Bank of America, Morgan Stanley, Societe Generale, Deutsche Bank, HSBC, Barclay's, Credit Suisse,
Goldman Sachs, JP Morgan and (NG) in order to develop and apply the technology. The next secto to have recognised the potential of blockchain is energy production, in which cryptography is excellently suited for keeping track of transactions involv ing energy between its small producers, such as, fo necessarily represented by large operators, but, for instance, the owners of electric cars.

Let us think about what is the ideal of the city in which we would like to live in. First, as Richard Senne wrote, it should be clean and safe, second, it should
have effective services supported by a dynamic economy. Third, it should support and shape cultural development, while its leaders should put all the necessary efforts in order to heal social and ethnic divides. He had claimed that cities in which we curus down in these matters due to government policy with irreparable social diseases and loss of social capital being beyond local control. [6] What is it then
that brings us closer to the idea of a modern city? A that brings us closer to the idea of a modern city? At
one time, the fresh but utopist vision by Le Corbusier one time, the fresh but utopist vision by Le Corbusier
concerning the centre of the city of Pars, the plan Voisin [7], would effectively result in killing off any public life at street level and the isolation of functions within areas and structures, without even mentioning the destruction of the incredibly rich and precious historical urban tissue. It was the most radical idea Paris with a metropolis of 3 million people with new, sixty-storeys-high residential towers planned on a regular circulation grid and surrounded by greenery and recreational spaces. From a later perspective we can observe that not all visionary thought
are assessed positively or are justified, however they surely are an element in the discussion on the subject of the development of civilisation.

1961 saw the publication of the book "The Death and Life of Great American Cities" by Jane Jacobs [8], which raised doubt about then-current meth-
ods of planning and redeveloping cities. The author engaged in a dispute with the utopian visions of $L$ Corbusier, in which dense and low urban built envi- oceny lub są słuszne, lecz z pewnością są elementem dyskus j $w$ temacie rozwoju cywilizacji.

W 1961 roku została wydana książka „Śmierć i życie wielkich miast Ameryki" Jane Jacobs [8], która poddaje pod wątpliwość słuszność obowiązujących dotychczas metod planowania i przebudowywania miast. Autorka polemizuje z utopijnymi wizjami Le Corbusiera, w których gesta i niska zabudowa miejska ustepuje miejsca wysokościowcom zatopionym w zieleni, a tradycyina siatka ulic zastapiona zostaje auto-

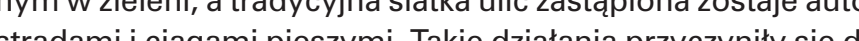
degrad iji wielu dziezyic Nowe Jorku i nie tylko, a szię do

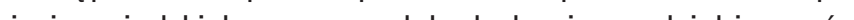
więzi sásiedzkich oraz upadek drobnej przedsiębiorczosci pozornie chaotyczne dzielnice, sa tak naprawde naim ziek pozomie chaotyczne dzielnice, są tak naprawdę największym

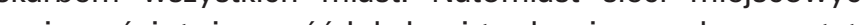
zajo inosci, tożs mosc lokalna i tradycyjne, male warsztaty, czy inne usługi, skladaja się na obraz dobrze funkcjonujące dzielnicy, zarowno pod względem spolecznym, jak i ekono micznym. W przeciwieństwie do teorii corbusierowskiej Jane Jacobs reprezentuje ideę otwartego miasta i społeczenstwa. Dziś należlo by też spojzzec raczej krytycznie na projektowanie miast. Richard Sennett uważa iż paradoks współczesnyc projektantów urbanistów polega na tym, iż dziś dysponujemy zaawansowana technologią, arsenatem rozwiązan technicznych, symulacjami, wizualizacjami, a pomimo to wydaje sie jakby przed laty, przy pomocy dawnych narzędzi, projektowato się bardziej wydajnie, czy kreatywnie, lepsze miasta.

Czy zatem kapitał i chęć jego pomnażania nie zaczął zastępować miejsca rzeczom potencjalnie bardziej istotnym jak Idei Współczesne miasta rozwijają się coraz bardziej dynamicznie obiekty i struktury mają inny cykl życia, a tempo metamorfozy obrazuja nieustannie zmiany przedstawiajac aglomeracje jako wielkie place niekończacej się budowy Obecnie budynki sa cześciej burzone niż adaptowane dla nowych funkcii, czyniac miasta szczególni podatne na rozpad i brak czytelności strukury urbanistycznej. Przecietny żywot budynków publicznych w Angli wynosi 40 lat a budynków biurowych, wysokściowych w Nowy namiczie roz niz zycia i pracy niz w Ey dop w wSA doprowadzila do powstan chero przsycrych dé ery rozwoju przenysly samochodowego przedmiesc, koro poprzez swoją powtarzalnośc zatracity unikalność, a powszechna migracja ludności motywowan ekonomią ry a pracy, sprzyjala niekontrolowanemu rozlewaniu się obszarów suburbiów. Ekonomia ma szalenie istotny wpływ na urbanistykę miast, a także na architekturę mieszkaniowa. Czy zatem w aglomeracjach dynamicznie rozwijającyc się da się zapanowac nad ich strukturą, kóra nieustannie ulega zmianom, a jej elementy przewartościowaniu? W Europie życie i zamieszkiwanie obszarow miejskich jest bardzo złozzona problematyką, gdzie wątki kulturowe, historyczne, teraźniejsz i troski o przyszłosć otoczenia, jego jakości, położenia względem miasta, jak również komunikacji publicznej, odgrywaja istotną rolę, poza potrzebą korzystania z osiedla, marketu, czy też miejsca pracy. Rozwiązania europejskie nie cechują się roz ronment had been replaced with high-rises steeped in greenery and the traditional grid of streets replaced with highways and pedestrian walkways
Such actions have led to the degradation of many districts of among other cities, New York, with the artificial and unfriendly urban structure causing among other things, a rise in crime rates, a lower sense of safety, the decay of neighbourly ties and the fall of small businesses, including local comseemingly chaotic neighbourhoods were actually the greatest treasure of all cities. Meanwhile local contact networks, the local identity and traditiona small workshops or other services made up the im age of a well-functioning neighbourhood, both i er's theory, Jane Jacobs represented the idea of an open city and an open society.

Today we should also take a rather critical look at the planning of cities. Richard Sennett believed that the paradox of contemporary urban designers was based on the fact that we currently have
advanced technology at our disposal-an arsenal of technical solutions, simulations and visualisations-and despite all this it seems as if years ago,
with the use of past tools, better cities were deeffectively or creatively.

Has capital and the desire to multiply it not begun to replace the things that are potentially more es-
sential, like Ideas? Contemporary cities are developing in an ever more dynamic manner, buildings and structures have a different life-cycle, and the served when presenting agglomerations as enomous sites of never-ending construction. Buildings are currently more often being demolished rather than adapted to new forms of use, making cities particularly susceptible to decay and a lack
of legibility in their urban structure. The average lifespan of public buildings in Great Britain is 40 years, while that of office high-rise buildings in New York is as little as 35 , or even 10 years in the case of the dynamically developing cities of China. of life and work than in Europe has led to the emerof the development of the automobile industry, motivated by the economy of the employmen market has been conducive to the uncontrolled sprawling of suburban areas. The economy has
a highly essential impact on the urban planning of cities and on residential architecture. Can we gain
control over their structure-that is constantly
undergoing changes while its elements are being undergoing changes while its elements are being
re-evaluated-in agglomerations? In Europe, life re-evaluated-in agglomerations? In Europe, life
and housing in urban areas is a highly complex subject, where cultural, historical and contempo-
rary threads, as well as worries about the future of the surroundings, its quality, location in relation to the city, as well as public circulation play a significant role in addition to the need to make use of pean solutions are not marked by the sprawling of urban tissue, but the repairing of existing spaces, something that is demonstrated by the various historical layers and the development of urban plancities that are, for instance, being founded from scratch. European urban planning is the site of a phenomenon that has been emerging over many 
lewaniem tkanki miejskiej, ale naprawianiem istniejących przeurbanistycznej na przestrzenie dekad, w przeciwieństwie do innych miast sytuowanych np. od nowa. Urbanistyka Europejska jest miejscem fenomenu powstającego na przestrzeni lat którego nie da się skopiować, o czym świadczyć może próba przeniesienia kanałów weneckich do Las Vegas lub przykłady kopiowania miast europejskich w Chinach.

Dynamiczny rozwój ekonomii i przemysłu w oparciu o wydobycie ropy naftowej zmienit na przestrzeni ostatich deko mape inwestycii kapitatu námiecie a skutkowat pojawie niem się nowych silnych finansowo metropolii. Jedną z nich jest Dubaj, nazwany mianem miasta przyszłości, który zaczyna przypominać miejsce z futurystycznych filmów. Wkrótce maja tam zagościć roboty policyine, latające taksówki oraz autonomiczne pojazdy. Emiraty Arabskie posiadają nawet ministra odpowiedzialnego za Sztuczną Inteligencję, a plany władz są tak ambitne, iż wkrótce stworzą pierwszy na świecie rząd oparty na technologii blockchain. Smart Dubai, to jednostka ktora prowadzi badania rządowe oraz na zlecenie prywatnych organizacji i ma ona za zadanie zidentyfikować usługi, które poprzez nowe technologie można by zintensyfikować. Strategia taka może zaoszcędic 25,1 milionów roboczogodzin lub 1,5 miliarda dolarów [9] rocznie dla państwa. Ponadto rynek nieruchomości oraz usług w tym sektorze także ma zostać radykalnie zautomatyzowany. Sposob w jaki ludzie kupują, sprzedają i dzierżawią nieruchomości, a nawet korzystaja $z$ dostawcow mediow ma posiadac obsługe jedynie cyfrowa. Agencja rządowa, której zadaniem było nadzorowanie zakupu gruntów i zatwierdzanie transakcji na rynku nieruchomości (Dubai Land Department), w październiku uruchomiła system oparty na blockchain, w celu lepszego zabezpieczenia transakcji finansowych, prowadzenia elektronicznego rejestru wszystkich umów dotyczące nieruchomości oraz połączenia właścicieli domów, najemców z usługami operatorów mediów. "Jak powiedział w oświadczeniu prasowym Sultan Butti bin Mejren, dyrektor generalny DLD, technologia, dzięki swoim możliwościom ma zapobiegać nadużyciom finansowym może wpływać na zdobycie zaufania tysięcy globalnych inwestorów w Dubaju" [10]. W październiku emirat uruchomił również własną kryptowalutę opartą na blockchain, zwaną emCash, którą ludzie mogą płacić za usługi rządowe i nie tylko. Ali Ibrahim, zastepca dyrektora generalnego ds. Gospodarki Dubaju w oświadczeniu prasowym powiedziat, iż cyfrowa waluta ma różne zalety - szybsze przetwarzanie danych transakcji, mniejszą złożoność i koszty, a wprowadzenie jej poprawi jakość życia w Dubaju. Nowa strategia to nowe wyzwania i niezidentyfikowane jeszcze problemy które miasto chce przezwyciężyć prowadząc wspólną platformę wdrożeniowa w różnych projektach wraz z nowymi startupami oraz $z$ wiodącymi na świecie firmami $w$ branży IT. Dubaj wraz z rządem i organizacjami pozarządowymi, w kooperacji ze światowymi gigantami technologicznymi realizuje program emisji walu akceptowalnej do transakcji finansowych przez inne kraje. Firma Planning Korea, należąca do sektora CPM [11], a działająca w zakresie nowoczesnych rozwiązań dla architektury miejskich, zatrudniająca architektów i artystów, podczas kon- many years, one that cannot be copied-a fact that has been proven by attempts to place Venetian canals in Las Veg.

Dynamic economic and industrial development on
the basis of oil production has changed the map of capital investment around the world over the pas decades and has resulted in the emergence of new financially strong metropolises. One of such metrop-
olises is Dubai, which has been called a city of the future, and which is starting to resemble a place toke tre, and which is starting to resemble a place take
from futuristic films. It is soon to become a host to police robots and autonomous vehicles. The United Arab Emirates even have a minister responsible for Artificial Intelligence and the plans of the authorities
are so ambitious that they will soon create the first government in history to be based on blockchai technology. Smart Dubai is a unit which carries ou government research, as well as studies commissioned by private organisations and has been given the task to identify services that can become intensi-
fied. This strategy can help the state to save up to
25,1 million working hours or 1,5 billion dollars $[9]$ per year. Furthermore, the real estate and services market in this sector is also to become radically automated. The manner in which people buy, sell and rent real estate and even interact with infrastructure
providers is to be handled solely in a digital $\mathrm{mat}$ ner. The government agency whose task is the supervision of the purchase of land and the approval of transactions in the real estate market (the Dubai Land Department) set up a blockchain-based syster cial transactions, the operation of a digital registry of all contracts concerning real estate and connecting land owners and renters with the services of infrastructure providers. As Sultan Butti bin Meyrem, the general director of DLD, stated in his press statement, the technology, thanks to the possibilities that
it offers, was meant to prevent financial abuse and could lead to gaining the trust of thousands of glob investors in Dubai [10]. In October the emirate also established its own cryptocurrency based on blockchain technology, called em Cash, which can be paid with for, among other things, government services
Ali lbrahim, the deputy general director concerning the Economy of Dubai, said in a press statement that
the digital currency has various advantages-the quicker processing of transaction data, less complex ity and cost, and that its introduction would improve the quality of life in Dubai. The new strategy also
means new challenges and currently unidentified problems that the city wants to overcome by running a joint implementation platform for various projects
along with new start-ups and the world's leading IT along with new start-ups and the world's leading I
companies. Dubai, along with the government and companies. Dubai, along with the government and
non-government organisations, in cooperation with non-government organisations, in cooperation with
global tech giants, is implementing a programme of the emission of a currency that is acceptable in financial transactions by other countries. The Planning Korea company, which belongs to the CPM sector [11], and which operates primarily ture, employing architects and artists, presented its original and highly interesting program: Connectivity of Smart City - The Smart Bridge and Blockchain City [12] at a press conference that took place on
the 26 of October 2017 in Seoul. The organisation is creating a new paradigm in the planning of ies. According to new objectives resulting from an analysis of current processes, the structure of the ferencji która odbyła się 26 października 2017 r. w Seulu, za-

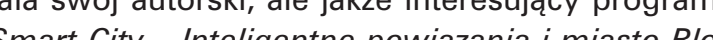
prest City - Inteligentne powiązania i miasto Blockchain. [12]. Organizacja zajmuje się stworzeniem nowego paradygmatu planowania miast. Według nowych założe sta zmieniać się będzie w kierunku hiperpołązzonego społeczeństwa miejskiego (człowiek-człowiek maszyna-człowiek maszyna-maszyna) siccia telekomunikacyina i nternetem, skzyia nas, aby ponownie przemyśleć filozofie egzystenci funkcjon a by ponownécín wy rośnie wykładniczo. Według autorów nowego paradygmatu czeka nas rewolucja w projektowaniu miast i zdecentralizowanie planowania. W dobie ery Internetu relacja poprzez dzielenie sie wiedzą i informacjami ma kluczowe znaczenie, podczas gdy miasto w przyszłości będzie Miastem według wymagań obywatell, ktore odzwierciedla indywidualne potrzeby i gusta. Teraz jesteśmy na początku hiperpolączonego spoleczensstwa. Jest ono ściśle związane z technologią blockchain, o której należy wspomniec. [13] Czekają nas rownież zmiany w modelac konsumpcil, w ktowych nalezy dostrze wzmocnienie lokalnej gospodarki oraz większą partycypację obywateli w życiu mie skm, w administracil oraz w usprawnienlu inicjatyw oddolnych wplywających na rewitalizację struktur i ich rozproszenie. Obecnie następuje czwarta rewolucja przemystowa, czyli Al, loT, Cloud, Big data i Mobile w oparciu o SmartCity (sztuczna inteligencja, internet rzeczy, chmury danych, ważne wielkie dane, mobilne urzadzenia, komputery w służbie miast inteligentnych). W przyszłości technologie te będą wiodącymi gałęziami przemysłu i odgrywać będą kluczową rolę w rozwoju systemów miejskich. Sztuczna inteligencja to technologia dynamicznie rozwijajaca sie i wykorzystywana beedzie do poprawy infrastruktury oraz bezpieczeństwa. Wpłynie to na wydajność spoteczeństwa i konkurencyiność $Z$ kolei chmura danych jest podstawa do analiz w czasie rzeczwstymi whozystania obrazo nych z serwerów danych. Jest to ustuga przydatna w Smab cebraw seks nego. Połączenie niezliczonej liczby sensorów i urządzeń pozwala aby miasto działało sprawnie jak komputer.

Duże dane pomagają wizualizować stale zmieniający sie świat a cyfrowy model 3D zintegrowany $z$ dynamicznymi danymi a cyfrowy model $3 D$ zintegrowany $z$ dynamicznymi danym wie problemów zwiazzanych z planowaniem przestrzennym dot. energii, logistyki, hałasu i uwarunkowań miejsca. Obecnie istniejące systemy finansowe są skomplikowane, zarządzane przez wielu operatorów, którzy otrzymuja prowizje. rządzane przez wielu operatorów, którzy otrzymują prowizje. System blockchain nie wymaga pośredników, takich jak bank czy firma finansująca. Jest to rdzen krypto-systemu, blockchain, ktory buduje zaufanie międzyosobowe. Airbnb i Uber to przedstawiciele gospodarki dzielenia się. Wlaściwości systemu blockchain jak: Indywidualnośc i Przejrzystośc; Dyspersja; ochrona danych osobowych, są bardzo ważnym zagadnieniem. Informacja zamknięta w blockchain, nie może zostac ujawniona bez zgody. Istnieja dwa kluczowe zastosowania te technologii. Pierwszym z nich to wykorzystanie blockchain city will change in the direction of an urban society that is hyperconnected (man-to-man, machine-to-man, machine-to-machine connections Internet, which encourages us to once more rethink the philosophy of the existence and functioning of an urban society. The amount of devices that are connected to the network, both in businesses and the administration, as well as across households, is the new paradigm, we ace in for a revolution in the designing of cities and a decentralisation of planning. They claimed that in the era of the Internet, relationships formed through the sharing of knowlthe city of the future would be a city built ince, as dance with the needs of citizens, one that reflected individual needs and tastes. They stated that we were at the beginning of a hyperconnected society and that it was strictly tied with blockchain technol as well ones in which we are to see a strengthening of the local economy and a greater participation of citizens in urban life, in administration and in making grassroots initiatives that affect the revitalisation
of structures and their dispersal more efficient. The a revolution based on $A 1$ the lnternet of Things Cloud Computing, Big Data and Mobile devices, al based on the Smart City. In the future these technologies will be the leading branches of industry and will play a key role in the development of urba dergoing dynamic development and will bogy unimprove infrastructure and security. This will affect the productivity of society, as well as competitiveness. Cloud computing, in turn, is the basis for realdata servers. It is a service that is useful in a Smart of sensors and devices makes it possible for a city to work as effectively as a computer does.

Big Data helps us to visuallse the constantly changreal-time dynamic data makes it possible to perform simulations and solve problems associated with spatial planning, concerning energy, logistics, noise and site-specific conditions. Current financia systems are complicated, managed by numerous systems do not require intermediaries such as a bank or financing company. It is the core of the crypto-system, a blockchain that builds interpersonal trust. Airbnb and Uber are representatives of
the sharing economy. The properties of the blockthe sharing economy. The properties of the block-
chain system, such as Individuality and Transparency, Dispersion and personal data protection are very important issues. Information enclosed in There are two key implementations of this technology. The first is the use of blockchain as an oper-

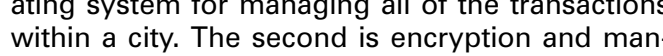
aging personal information within a blockchain. If a blockchain city is to be established, it will be come a decentralised city for its community, within which the power of control, energy, transport an privacy of registered users in a Smart City and will transparently manage all transactions within it. En- 
jako operacyjnego systemu zarządzania dla wszystkich transmi osobowymi w blockchain. Jeśli miasto blockchain zostanie zrealizowane, stanie się zdecentralizowanym miastem dla społeczności, w którym dystrybuowana jest siła kontroli, energia, transport i bogactwo. Blockchain w Smart City w pełni chroni prywatność zarejestrowanych osób i beedzie w przejrzysty sposób zarządzał wszystkimi transakcjami w mieście. Zarzadzanie energia może dotyczyć różnych kierunków, natomiast potaczyć je można z masowym lub jednostkowym gromast połajednostek przeliczanych na kryptowalute. Pojawi sie wysoko rezwiniety transpot auton kiczny zám. Po kotowy wience wietrany. Cery

W czwartej rewolucji przemysłowej to właśnie smartphony i inne mobilne urzadzenia odgrywają kluczową rolę. Są one najsprawniejszymi protezami ludzi: encyklopediami, mapami, poradnikami, wyświetlaczami mediów i niczym szwajcarski scyzoryk wykorzystuja oprogramowanie do aplikowania szerokiej funkcjonalności. To, co będzie nas zaskakiwać to coraz większa integracja technologii i człowieka, w którą inwestuja koncerny, jak np. rozwiązzania wirtualnej rzeczywistości oraz inteligentny rynek medyczny. Przewidywania ekonomistów kierują uwagę na branże FinTech, która generuje obecnie największy ruch w Internecie. Wiele z naszych najpotężniejszych nowych technologii, takich jak sztuczna inteligencja, budowana jest z wykorzystaniem sposobu wspierającego status quo centralizacji i konsolidacji. Blockchain funkcjonuje zupełnie przeciwnie. JP May zauważył [14], iż obecnie wchodzimy w epokę „Suwerennej jednostki, która to coraz częściej przejmuje role wcześniej wykonywane przez korporacje i rządy, tworzạc popyt na "twardsze" (bardziej pewne) pieniądze, które są blizsze gotówce niż kredytowi" [15]. Pomimo iż waluta w Internecie jest wirtualna, to należy ona do grup konkretnych osób, które będą dążyć do omijania centralnych instytucji.

\section{Podsumowanie}

Utopia typu blockchain może przyjać forme pluralistycznego ekosystemu, w którym wiele "suwerennych jednostek" i mniejszych grup wypracuje swoje własne enklawy, terytoria, które dziś, w ramach kontroli prowadzą rządy, wielkie banki oraz miedzynarodowe korporacje. Gdzie zatem skupi sie nowa władza i jaka forme przyjmie? Czy będzie ona demokratyczna i czy zagwarantuje włásiwy porządek? Oczywiście prezentowany jest tu tylko wyidealizowany scenariusz, a ekosystem blockchainów może jeszcze okazać się podatny na centralizacje, czy formy systemów praworzadnych. Wpływ Internetu i urzadzeń mobilnych na środowisko miejskie, do tkną już prawie każdego aspektu życia. Począwszy od roli handlu detalicznego (handel w Internecie), usług transportowych (Uber) po proste poruszanie się po nieznanych ulicach (mapy i przewodnik). Czy blockchain będzie mial porównywalne efekty? Miasto inteligentne (SmartCity), które dziś reprezentowane jest przez centralne zarządzanie danymi, może rozwijać się dalej dzięki technologii w zupełnie nowy twór z inną hierarchią elementów. Czy zatem budujemy w głowach kolejną utopię? Film Metropolis (Fritz Lang) przedstawiał nie- ergy management can concern various directions, including combining it with either the bulk or individual gathering of units that can be converted to cryptocurrency. Highly advanced autonomic certification of purchases, products and foodstuffs will become more advanced.

In the fourth industrial revolution it is the smartphone and other mobile devices that play a key role. they are encyclopaedias, maps, guides, media displays and, like a Swiss-army knife, use software that has very broad functionality. That which will surprise us is the increasing integration of technology virtual reat that corporations are investing in, such as ket. Forecasts by economists direct our attention to the FinTech sector, which is currently generating the greatest Internet traffic. Many of our most powerfu new technologies, such as artificial intelligence, are the status quo of centralisation and consolidation Blockchain works in the exact opposite manner. JP May observed [14] that we are currently enterin a period of the sovereign individual, who more and more often takes over roles that were previously ating a demand for "harder" (more reliable) currency, which is closer to cash than credit [15]. Despite the fact that Internet currency is virtual, it belong to a group of specific individuals who will strive to central institutions.

Summary

A blockchain-type utopia can take on the form of a pluralist ecosystem in which many "sovereig inn controlled by governments, large banks run and national corporations. Where, then will the government gather and what form will it take? Will it be democratic and ensure proper order? $O$ course, only an idealised scenario is presented here and the blockchain ecosystem can yet turn out to law-biding systems. The influence of the Internet and mobile devices on the urban environment has touched practically every aspect of life. Starting with the role of retail (online trading), transport services (Uber) to simple movement along unfamiliar street (maps and guides). Can blockchain have a comresented by central data management can develop further thanks to technology into a completely new entity with a different hierarchy of elements. Are we building yet another utopia in our heads, then? The perfectly functioning scenario, but that was perfect only for a time, as the perfect machine did fail at one point. Apparently, it is in our nature to seek perfect systems. According to the American sciencefiction writer Bruce Sterling [16], blockchain, if
comes, will change cities just like the Internet starting from the most fundamental reasons for the existence of cities: trading, transactions and the exchange of information. Visionaries of the future such as Fritz Lang (the film Metropolis) Le Corbusier simistic image of the world, but the reality that is coming can turn out to be much more optimistic. Blockchain technology is already functioning in, for gdyśs pewien idealnie funkcjonujący scenariusz, ale tylko do rii. Widocznie w naszej naturze jest dażenie do idealnych systemów. Według amerykańskiego pisarza science-fiction Brucea Sterlinga [16], blockchain, jeśli nadejdzie, zmieni miasta tak, jak zrobił to wcześniej Internet, zaczynając od najbardziej fundamentalnych przyczyn istnienia miast: handlu, transakciji wymiany informacii. Wizjonerzy przyszłości jak Fritz Lan film Metropolis) Le Corbusic przedsta is nam pesymistyczny obraz śwata, ale nastepuprza rzeczy nstość może okazá́ się znaczni bardziej opyopry rejestracji pojazdów, a liczne kopalnie łań zajmują się pisaniem kodów i „kopaniem” wirtualnego pieczę̧ść pracy maksymy, iż w przyszłości znacznie większa

PRZYPISY

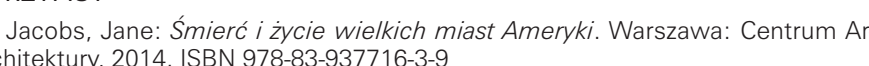

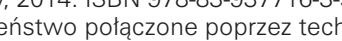

Kryptowaluta cyfrowa - https:///pl.wikipedia.org/wikiki/Bitcoin obligatoryjny.

edrzycki.p//blockchain-

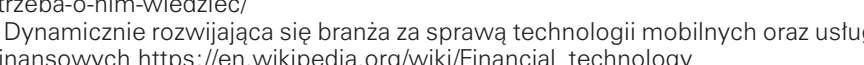

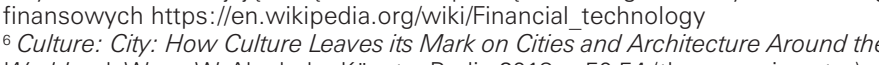
World red. Wang W. Akad. der Künste, Berlin 2013 , s.50-54 (ttumaczenie autor)
'Plan radykalnych zmian w centrum Paryzia autorstwa Le Corbusiera z 1925 roku

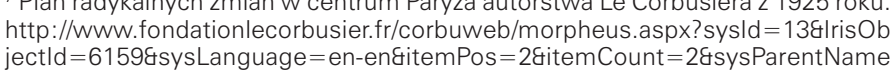

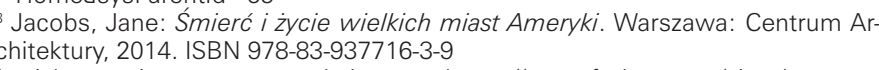
jak napisano $w$ artykule - - https://Www.forbes.com/sites/suparna
dutt/2017/12/18/dubai-sets-sights-on-becoming-the-worlds-first-blockchain-po wered-government/\#345d829e454

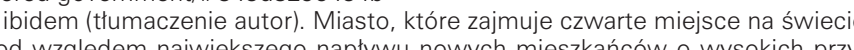

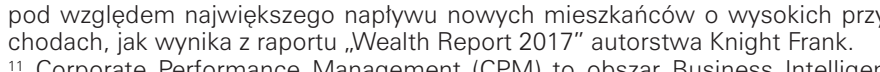

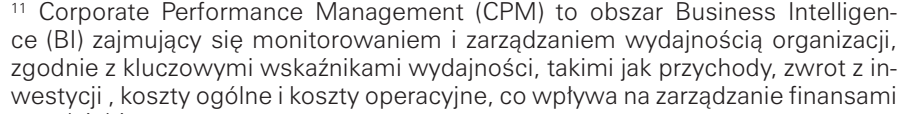
"Connectivity of Smart City - The Smart Bridge and Blockchain City" http

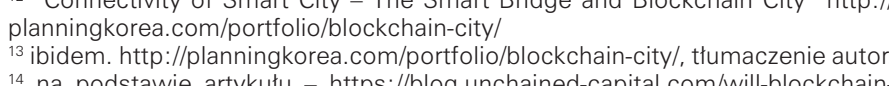
-save-cities-from-themselves-f23bbf $3541 \mathrm{bd}$
${ }_{15}$ skala wartości pieniadza https://jim.com/security/May_scale_of_monetary

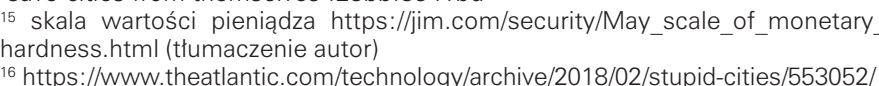
LITERATURA

11) Culture: City: How Culture Leaves its Mark on Cities and Architecture Around the World red. Wang W. Akad. der Künste, Berlin 2013, s.50 2 Jacobs, Jane: Smierć i życie willkich miast Ameryki. Warszawa: Centrum Architektury, 2014. ISBN 978-83-937716-3-9
[3] Wagner, S. C. - Poietry: Challenging Solitude and the Improbability of Com
munication, De Gruyter, Austria 2017

Źródta internetowe: [stan na 10.08.2018
https:///l.wikipedia.org/wiki/Bitcoin

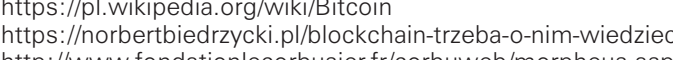

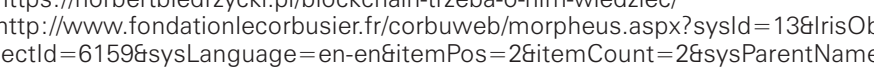
$=$ HomefsysParentld $=65$
https://wwww forbes com/sites/suparnadutt/2017/12/18/dubai-sets-sights-on-

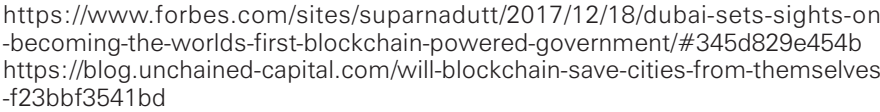
f233bbf3541 bd

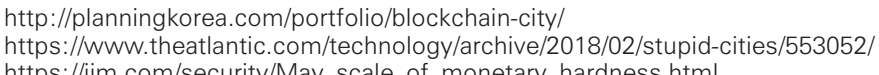

instance, Estonia, and is used there in the registration of vehicles, while the many blockchain mines te occupied with writing code and the "mining" of future a much greater part of our work will be performed by computers and machines.

ENDNOTES

1 Jacobs, Jane: Śmierć i iycie wielkich miast Amenrki. War-
szawa: Centrum Architektury, 2014. ISBN 978-83-937716-3-9

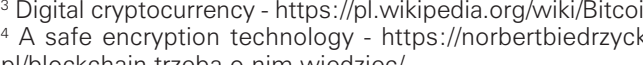
5 A dynamicallly develnoping -wiedziector due to mobile techno-
logies and financial services https://en.wikipedia.org/wiki/ "Culture."City: How Culture Leaves its Mark on Cities and ArBerlin 2013, p.50-54 (transl. by the author)
7 Le Corbusier's plan of radical changes to the centre of
Paris from 1925 htth //www fondationlecorbusierffrcorbu-

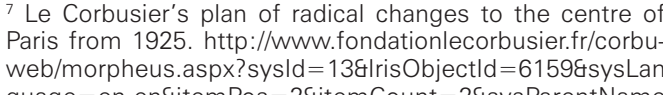

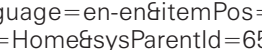

Jacobs, Jane: Smierć i zycie wielkich miast Amenkki. Wa

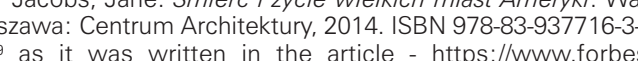

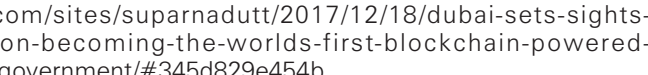
10 ibidem (translated by the author). It is the fourth city in
the world in terms of the size of the influx of new high-income residen
by Knight Frank.

Corporate Performance Management (CPM) is an area of and management of the efficiency of an organisation accor-
ding to key performance indicators, such as income, retur ding to key performance indicators, such as income, return
on investment, general and operation costs, which affects
the management

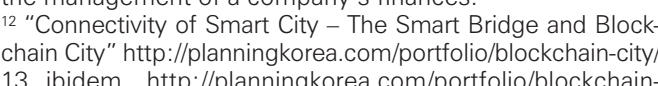
-city/, transil. by the author.
14 based on the article - http will-blockchain-save-cities.from theg.unchained-capital.com/ 15-blockchain-save-cities-from-themselves- $-23 \mathrm{bb}+3541 \mathrm{bd}$
the scale of a currency's worth https: ///im.com/security/
May scale of monetary hardness.html (translated by the May scale_of_monetary_hardness.html (translated by the
author) 15 https: //Www.theatlan
stupid-cities/553052/

\section{BIBLIOGRAPHY}

[1] Culture: City: How Culture Leaves its Mark on Cities and
Architecture Around the World red. Wang W. Akad. der Kün-

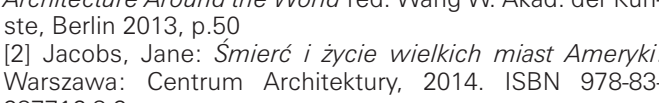
[3] Wagner, S. C. - Poietry: Challenging Solitude and the
Improbability of Communication, De Gruyter, Austria 2017

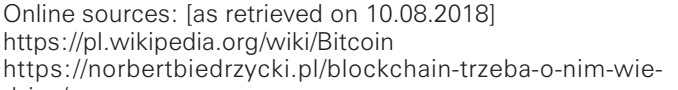

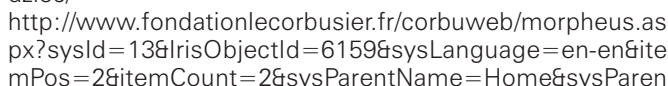
tldd $=65$
https://www.forbes.com/sites/suparnadutt/2017/12/18/ https: //Www.forbes.com/sites/suparnadutt/2017/12/18/
dubai-sets-sights-on-becoming-the-worlds-first-blockchain-
-powered-government/\#345d829e-454b

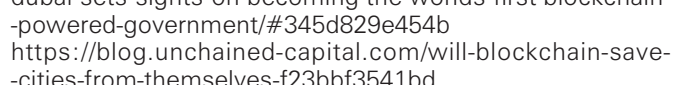
hittp://planningkorea.com/portfflio//blockchain-city/
https://www.theatlantic.com/technology/archive/2018/02/ stupid-cities/553052/
https://jim. $50 m /$ security/May_scale_of_monetary_hard- 